THE JOURNAL OF
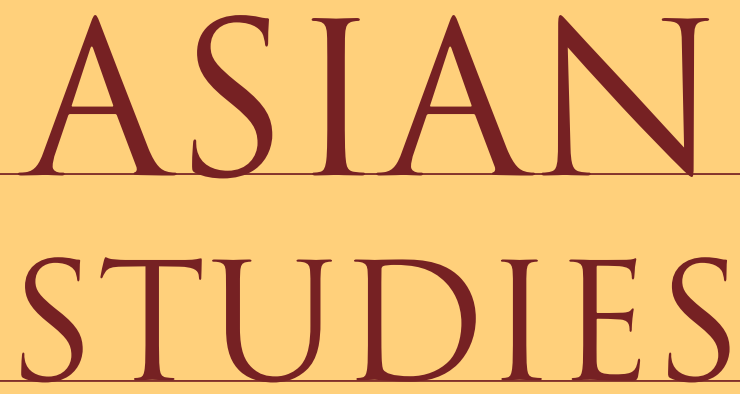

V O L U M E 69

N U M B E R 3

A UGUST 2010
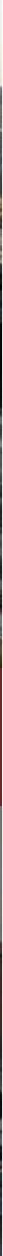

P U B L I S H E D F O R

THE AS S CIATION FOR

A S I A N T U D I E S, I N C. 


\section{The Journal of Asian Studies}

\section{Editorial Board}

Editor

Jeffrey N. Wasserstrom, University of California, Irvine

Associate Editors

China Antonia Finnane, University of Melbourne

Deborah Davis, Yale University

Inner Asia Gray Tuttle, Columbia University

JAPAN Jordan Sand, Georgetown University

Korea Robert Oppenheim, University of Texas, Austin

South Asia David Gilmartin, North Carolina State University Dilip Menon, University of Delhi

Southeast Asia Anne Hanson, University of Wisconsin-Madison

Book Review Editors

Asia: Comparative and

Transnational Daniel Little, University of Michigan-Dearborn

China Beverly Bossler, University of California, Davis

Mark Halperin, University of California, Davis

Kristin Stapleton, University at Buffalo, SUNY

Inner Asia Lauran Hartley, Columbia University

Japan Stephen Vlastos, University of Iowa

Korea Seungsook Moon, Vassar College

South Asia Deepak Sarma, Case Western Reserve University

Southeast Asia Jennifer Munger, University of California, Irvine

\section{Editorial Staff}

$\begin{aligned} \text { Managing Editor } & \text { Editorial Assistant } \\ \text { Jennifer H. Munger } & \text { Miri Kim }\end{aligned}$

\section{Liaison to Sponsors}

Katherine Haines, Assistant Dean, School of Humanities;

Marc Kanda, Department Manager, History Department

Sponsoring Institutions:

School of Humanities, History Department and Center for Asian Studies, University of California, Irvine; University of Michigan 


\section{THE JOURNAL OF ASIAN STUDIES \\ VOLUME 69 ' NUMBER 3 - AUGUST 2010 \\ CONTENTS}

Editorial Foreword and Forthcoming Articles

665

\section{ARTICLES}

Asia Beyond the Headlines

Forum on Transnational Extravaganzas

Expo 2010: A Historical Perspective

Susan R. Fernsebner

Delhi and CWG2010: The Games Behind the Games

Kalyani Menon-Sen

From 2008 to 2010: Big-Ticket Spectacles in China and India

683

Pallavi Aiyar

An Ordinary Country

687

Dilip Menon

\section{Research Articles}

The Apocryphal Suicide of Saigō Takamori: Samurai, Seppuku, and the Politics of Legend

Mark J. Ravina

The Great Rumor Mill: Gossip, Mass Media, and the Ninja Fear

Nicholas Herriman

Inauthentic Sovereignty: Law and Legal Institutions in Manchukuo

Thomas David DuBois

Making Family and Nation: Hindu Marriage Law in

Early Postcolonial India

Narendra Subramanian 
Egalitarian Developmentalism, Communist Mobilization,

and the Question of Caste in Kerala State, India

J. Devika

Modern Art Patronage and Democratic Citizenship in Japan

Laura Hein

Drumming from Screen to Stage: Ondekoza’s Ōdaiko

and the Reimaging of Japanese Taiko

Shawn Bender

\section{BOOK REVIEWS}

\section{ASIA: COMPARATIVE AND TRANSNATIONAL}

Béguin, Buddhist Art: An Historical and Cultural Journey

Rebecca Hall

Lall and Vickers, eds., Education as a Political Tool in Asia

Lakshmi Narayanan

Solinger, States' Gains, Labor's Losses: China, France,

and Mexico Choose Global Liaisons, 1980-2000

Marc Blecher

\section{CHINA}

Hayot, The Hypothetical Mandarin: Sympathy, Modernity, and Chinese Pain

Michael Berry

Huang and Henderson, eds., Notions of Time in

Chinese Historical Thinking

Anthony E. Clark

Jiang, Women Playing Men: Yue Opera and Social Change

in Twentieth-Century Shanghai

Joshua Goldstein

Joiner, Honorable Survivor: Mao’s China, McCarthy's America, and the Persecution of John S. Service

Maochun $\mathrm{Yu}$ 
Knapp and Ong, Chinese Bridges: Living Architecture

from China's Past

Tracy Miller

McKeown, Melancholy Order: Asian Migration and the

Globalization of Borders

883

Erika Lee

Twitchett and Smith, eds., The Cambridge History of China,

Volume 5, Part 1, The Sung Dynasty and Its Precursors, 907-1279

885

Patricia Buckley Ebrey

Yan, New Masters, New Servants: Migration, Development,

and Women Workers in China

Jieyu Liu

Zheng, Red Lights: The Lives of Sex Workers in Postsocialist China

890

Jieyu Liu

\section{INNER ASIA}

Jackson, Patron and Painter: Situ Panchen and the Revival of the Encampment Style

Nancy G. Lin

Pirie and Huber, eds., Conflict and Social Order in Tibet

and Inner Asia

Christopher P. Atwood

Srinivasan, ed., On the Cusp of an Era: Art in the Pre-Kusāna

World

Jamsheed K. Choksy

\section{JAPAN}

Bourdaghs, Ueda, and Murphy, eds., Theory of Literature

and Other Critical Writings/Natsume Sōseki

Marvin Marcus

DiNitto, Uchida Hyakken: A Critique of Modernity and

Militarism in Prewar Japan

902

David R. Ambaras 
Friday, The First Samurai: The Life and Legend of the

Warrior Rebel Taira Masakado

Joan R. Piggott

Hotta, Pan-Asianism and Japan's War 1931-1945

907

Yuka Hiruma Kishida

Takeshi, Soft Power and Its Perils: U.S. Cultural Policy in

Early Postwar Japan and Permanent Dependency

909

Christopher Gerteis

Najita, Ordinary Economies in Japan: A Historical Perspective, 1750-1950

James W. White

Nygren, Time Frames: Japanese Cinema and the Unfolding of

History

Murray Leeder

Schaede, Choose and Focus: Japanese Business Strategies

for the 21st Century

Hiroshi Shimizu

Skya, Japan's Holy War: The Ideology of Radical

Shintō Ultranationalism

Christopher Ives

\section{KOREA}

Caprio, Japanese Assimilation Policies in Colonial Korea,

1910-1945

Alexis Dudden

Chun, Organizing at the Margins: The Symbolic Politics of Labor in South Korea and the United States

Jong Bum Kwon

Kim, trans., Questioning Minds: Short Stories by Modern Korean Women Writers

Ji-Eun Lee

Kim-Renaud, Korean: An Essential Grammar

926

Gregory K. Iverson 
Park, Who Ate Up All the Shinga? An Autobiographical Novel, trans. Yu and Epstein

Jin-kyung Lee

Suh, Power, Interest, and Identity in Military Alliances

930

Youngshik D. Bong

\section{SOUTH ASIA}

Bandyopadhyay, Decolonization in South Asia: Meanings

of Freedom in Post-Independence West Bengal, 1947-52

932

Narasingha Sil

Berkwitz, Schober, and Brown, eds., Buddhist Manuscript

Culture: Knowledge, Ritual, and Art

Jacob N. Kinnard

Bhatia, ed., Modern Indian Theatre: A Reader

935

Kristin Rudisill

Brittlebank, ed., Tall Tales and True: India, Historiography

and British Imperial Imaginings

Frank F. Conlon

Chatterji, The Spoils of Partition: Bengal and India, 1947-1967

939

Vazira Fazila-Yacoobali Zamindar

Majumdar, Marriage and Modernity: Family Values in

Colonial Bengal

Varuni Bhatia

Mohanty, Lectures on Consciousness and Interpretation

Douglas L. Berger

Patil, Against a Hindu God: Buddhist Philosophy of Religion in India

Matthew R. Dasti

Pauwels, The Goddess as Role Model: Sìtā and Rādhā in Scripture and on Screen

Phyllis K. Herman

Powers, Kites over the Mango Tree: Restoring Harmony between Hindus and Muslims in Gujarat

Eric J. Rothgery 
Powers, A Bull of a Man: Images of Masculinity, Sex, and the Body in Indian Buddhism

Amy Paris Langenberg

Shehabuddin, Reshaping the Holy: Democracy, Development, and Muslim Women in Bangladesh

Shelley Feldman

\section{SOUTHEAST ASIA}

Lingard, Refugees and Rebels: Indonesian Exiles in Wartime Australia

William Bradley Horton

Post, Frederick, Heidebrink, and Sato, eds., The Encyclopedia of Indonesia in the Pacific War

Mayumi Yamamoto 


\section{The Association for Asian Studies, Inc.}

\section{OFFICERS OF THE ASSOCIATION}

President-Kalyanakrishnan (Shivi) Sivaramakrishnan, Yale University

Vice President-Gail Hershatter, University of California, Santa Cruz

Past President-Robert W. Hefner, Boston University

Past-Past President - ROBERT BuswelL, University of California, Los Angeles

\section{BOARD OF DIRECTORS}

President, Vice President, Past President, and Past-Past President, as listed above. Editor, Journal of Asian Studies-Jeffrey Wasserstrom, University of California, Irvine China and Inner Asia Council-Matthew H. Sommer, Stanford University Northeast Asia Council-William M. Tsutsul, Southern Methodist University

South Asia Council-Ramya Sreenivasan, SUNY-Buffalo

Southeast Asia Council-Justin McDaniel, University of Pennsy/vania

Council of Conferences-Johan Elverskog, Southern Methodist University

Program Committee Chair-Allen HICKen, University of Michigan

\section{STAFF OF THE ASSOCIATION}

Executive Director-Michael PAschal

Comptroller-Alicia WiLLIAMS

Director of Development \& Strategic Planning-ROBERT SNOW

Conference Manager-ROBYN JONES

Membership Manager-DoReen ILOZOR

Publications and Website Manager-Jonathan WILSON

Publications and Advertising Coordinator-Gudrun PATton

Accounts Receivable, BAS Online-LISA Hanselman

Office Assistant-Teresa Spence

\section{SPONSORING INSTITUTIONS}

University of Michigan and University of California, Irvine.

To learn more about the Association, its publications, and its other activities, see the AAS website: www.asian-studies.org.

\section{JOIN US IN HONOLULU, HAWAII IN 2011}

A special joint meeting of the Association for Asian Studies and the International Convention of Asia Scholars

in celebration of

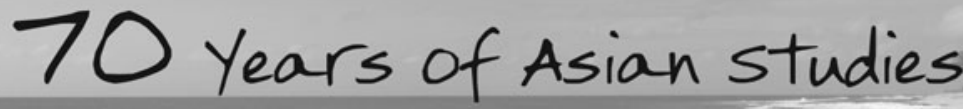

March 31-April 3, 2011

Hawai'i Convention Center, Honolulu, HI

For information visit www.asian-studies.org 